International Journal of Life Sciences
Available online at http://sciencescholar.us/journal/index.php/ijls
Vol. 3 No. 3, December 2019, pages: $1 \sim 7$
e-ISSN: 2550-6986, p-ISSN: $2550-6994$
https://doi.org/10.29332/ijls.v3n3.341

\title{
Ration Digest Value and Performance of Male Bali Ducks Feed Waste Wine Fermented with Different Levels
}

\author{
(CrossMark \\ A. W. Puger ${ }^{\text {a }}$ I. M. Nuriyasa ${ }^{b}$ \\ Article history: Received 09 May 2019, Accepted: 31 August 2019, Published: 27 September 2019
}

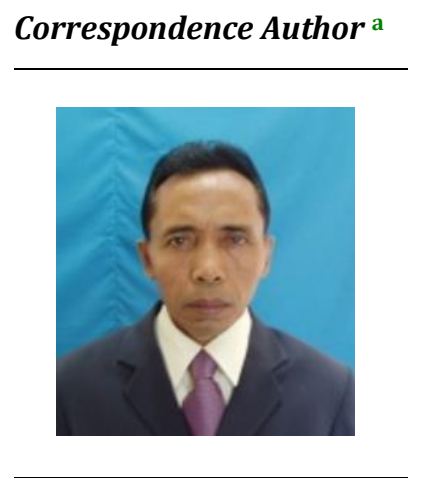

Keywords

grape;

male Bali ducks;

productivity;

wine waste,

fermentation;

\begin{abstract}
The research was intended at increasing the productivity of Bali ducks through the utilization of fermented wine waste. The study used a completely randomized design (CRD), four treatment rations, and five replications. There were 40 experimental units. Each unit of experiment used five ducks. The total of ducks used was 100. The treatments imposed on ducks were ducks fed with no fermented wine (R0), containing $5 \%$ fermented wine (R1), containing $10 \%$ fermented wine (R2), containing 15\% fermented wine (R3). The variables were examined namely performance, carcass, and digest coefficient. The results showed dietary consumption, final body weight, weight gain, and feed conversion did not show significant differences $(\mathrm{P}>0.05)$ among treatments. The conclusion is the use of fermented grape wine waste up to $15 \%$ level not significantly affect the digestibility of rations, the performance, and carcass of male Bali ducks.
\end{abstract}

e-ISSN: 2550-6986, p-ISSN: 2550-6994@ Copyright 2019. The Author. SS Journals Published by Universidad Técnica de Manabí. This is an open-access article under the CC BY-SA 4.0 license (https://creativecommons.org/licenses/by-sa/4.0/) All rights reserved.

\section{Contents}

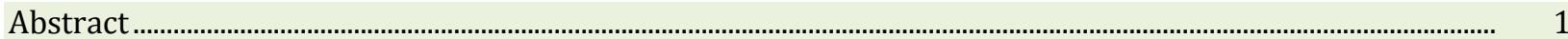

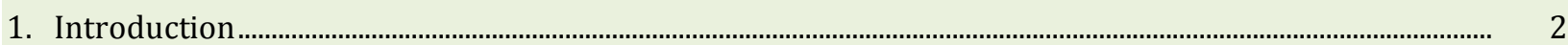

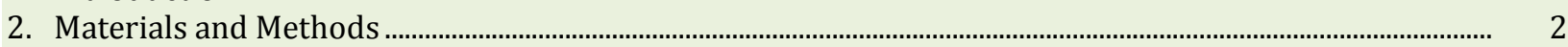

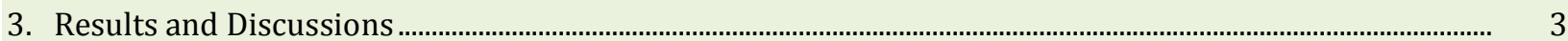

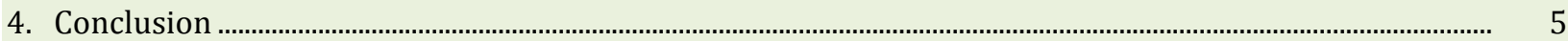

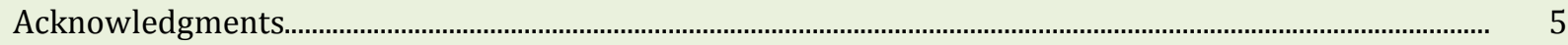

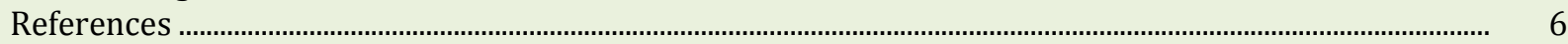

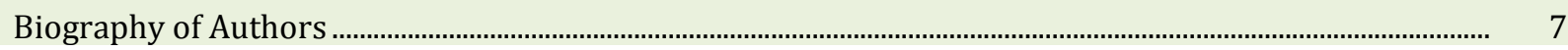

a Udayana University, Denpasar, Indonesia

b Udayana University, Denpasar, Indonesia 


\section{Introduction}

A feed is one of the environmental factors. It is very influential on the level of livestock production. Feeding must refer to the nutritional needed by livestock (Nuriyasa et al., 2017). Mastika (2013), reported one alternative for providing cheap and competitive feed is through the use of waste, both agricultural, livestock, and agricultural industrial waste. Buleleng Regency is a wine-producing center in Bali, total grape production in 2013 was 9,118 tons of fresh grapes, 50\% entered the wine processing industry (BPS Buleleng, 2018). Wines from the wine-making industry have enough nutrients for livestock. They are cheap and available continuously.

The wine industry's waste from grapes has considerable potential to be used as animal feed. Due to its high production. Processing wine into wine will produce waste in the form of seeds and skin about 40\%. Grape seeds and skin are rich in phenolic monomer components, for example, catechins, epicatechin, epicatechin-3O-gallate, and proanthocyanidins (in dimetric, trimetric, and tetrametric) forms. They have mutagenic and antiviral effects (Kim et al., 2006; Yadnya et al., 2016). The grape seeds generally contain 74-78\% oligomeric proanthocyanidin and less than $6 \%$ dry weight grape seed extract contains flavonoids that function as natural antioxidants. Voisinet et al., (1997), observed the use of rations with the addition of liquid wine waste from grapes will result in chemical changes in the meat becoming more tender. Moote et al., (2012), the use of grape wine waste about 7\% in male cow ration showed no significant difference in terms of body weight gain and meat color score compared to controls.

The fermentation process on EM-4 the protein content of wine waste from grapes can be increased from $17.79 \%$ to $27.05 \%$ and the content of digestive inhibitors can be reduced (Mahardhika et al., 2015). MolinaAlcaide et al., (2008), stated the fermentation of wine-making waste from grapes can be a source of protein and crude fiber suitable for ruminant animal feed. Rokhmani (2005), stated that fermented as rabbit ration at $10 \%$ and $20 \%$ levels can increase rabbit weight by $33 \%$ and $29 \%$ compared to those given without fermentation. Mahardika et al., (2017), the fermented ration of the protein and energy content increased, while the crude fiber content decreased. It shows on involving technology can make wine waste from grapes as higher-quality feed ingredients.

\section{Materials and Methods}

\subsection{Research design}

The study used a completely randomized design (CRD), four treatments and five blocks (replications). Each unit of experiment used five ducks. The total of ducks used was 100 . The research treatment was ration without using (0\%) wine waste fermented EM-4 (R0); ration using 5\% EM-4 (R1) fermented wine waste; ration using $10 \%$ EM-4 (R2) fermented wine waste; ration used 15\% EM-4 (R3) fermented wine waste. The nutrient content of the treatment ration was in the following Table 1.

Tabel 1

Nutrient content of the treatment ration

\begin{tabular}{lllll}
\hline \multirow{2}{*}{ Nutrient Content } & \multicolumn{3}{c}{ Treatment } \\
\cline { 2 - 5 } & R0 & R1 & R2 & R3 \\
\hline Energy metabolism (kcal/kg) & 2908,59 & 2911,36 & 2907,67 & 2907,40 \\
Protein (\%) & 16,08 & 16,09 & 16,03 & 16,09 \\
Calcium (\%) & 0,64 & 0,61 & 0,55 & 0,49 \\
Phosphor (\%) & 1,12 & 1,05 & 0,43 & 0,39 \\
Fat (\%) & 5,29 & 5,46 & 5,15 & 5,36 \\
Coarse fiber (\%) & 4,43 & 4,35 & 4,54 & 4,43 \\
\hline
\end{tabular}




\subsection{Variables observed (digestion)}

Digestion of dry matter, protein, and digestible energy were calculated based on ration consumption data and the content of dry matter, energy, and protein contained in feces. Dry matter digestibility $(K C B K)$ was calculated based on the total collection method (Tillman et al., 1989; Puger et al., 2019). The stool is stored for seven days, dried in the sun, to dry the air then roasted at a temperature of $60{ }^{\circ} \mathrm{C}$ for 24 hours. KCBK is calculated by formulation:

$$
\mathrm{KCBK}=\frac{(\mathrm{A}-\mathrm{B})}{\mathrm{A}} \times 100 \%
$$

Where: KCBK is the digestibility of dry matter (\%), A is the consumption of dry matter ration (g), B is the number of dry matter excreta (g). Digestible energy is calculated based on the total collection method (Prasad et al., 2010). It can be calculated using the formulation:

$$
(\mathrm{DE} / \mathrm{GE})=\frac{(\mathrm{A}-\mathrm{B})}{\mathrm{A}} \times 100 \%
$$

Where: DE/GE is digestible energy, $\mathrm{A}$ is consumption energy (kcal/day), $\mathrm{B}$ is the energy content in the stool (kcal/day). Protein digestibility (KP) is calculated based on the total collection method (Prasad et al., 2010). It can be calculated using the formulation:

$$
\mathrm{KP}=\frac{(\mathrm{A}-\mathrm{B})}{\mathrm{A}} \times 100 \%
$$

Where: KP is protein digestibility (\%), A is protein consumption (g/day), B is the protein content in feces (g/day).

\subsection{Performance variable}

Ration consumption is calculated every week by reducing the amount of ration given with the rest of the ration on that day. Total ration consumption is obtained by adding up the consumption of ration every week during the study. Weighing is conducted every week to get weight gain per week. Initial weight weighing was carried out at the beginning of the study to gain initial weight. Meanwhile, weight weighing was carried out at the end of the study to obtain final weight. To determine weight gain during the study carried out by reducing weight at the end of the study with weight at the beginning of the study. Before being weighed, the rabbit has fasted for 12 hours. Feed conversion ratio (FCR) is calculated by comparing the number of rations consumed with weight gain during the study.

\section{Results and Discussions}

\subsection{Digestion}

Digestion of dry matter ration was not significantly different ( $>>0.05)$ among treatments of diet R0, R1, R2, and R3. Dry matter digestibility was $64.57 \%, 64.15 \%, 64.66 \%$, and $64.58 \%$ for the treatment of R0, R1, R2, and R3 rations (Table 2). Tillman et al., (1998) \& Bagiarta et al., (1989), stated the digestibility of dry matter is closely related to the crude fiber content of the ration. The ration treatments R0, R1, R2, and R3 contain crude fiber not much different respectively 4.43; 4.34; 4.54; and 4.43\%. The crude fiber content did not differ caused the digestibility of dry matter. They did not differ among treatments R0, R1, R2, and R3. Table 2 shows the consumption of dry ingredients and fecal dry matter was not significantly different. The digestion of energy in Bali ducks treated with R0, R1, R2, and R3 rations did not show any significant difference.

Puger, A. W., \& Nuriyasa, I. M. (2019). Ration digest value and performance of male Bali ducks feed waste wine fermented with different levels. International Journal of Life Sciences, 3(3), 1-7. https://doi.org/10.29332/ijls.v3n3.341 
Baumgartel et al., (2007), stated grape seed extract is a good source of energy to support livestock production. The results of the study get different results with Baumgartel et al., (2007), due to energy consumption and energy contained in feces are not much different. The condition causes undigested energy in Balinese ducks were treated with rations with different levels of waste wine from cedar wine not showing any real difference. Table 2 shows protein digestibility was not significantly different. It is due to the consumption of protein and fecal protein content did not show significant differences. Other researchers, this insoluble residue from wine waste has a lignin content ranging from $16.8 \%-24.2 \%$ and low protein content. Cellulose is a type of polysaccharide in the form of cell walls owned by grapes, which vary from 27\%-37\% (GonzálezCenteno et al., 2014; Partama et al., 2018). Bali ducks protein content and the presence of lignin in the cell walls of grapes did not influence the consumption of protein and protein content in feces.

Table 2

Effect of wine waste used in rations on digestibility of male Bali duck ration

\begin{tabular}{llllll}
\hline \multirow{2}{*}{\multicolumn{1}{c}{ Variable }} & \multicolumn{4}{c}{ Treatment } & \multirow{2}{*}{ SEM } \\
\cline { 2 - 5 } & R0 & R1 & R2 & R3 & \\
\hline Consumption of dry material (g/day) & $60,17^{\mathrm{a}}$ & $60,58^{\mathrm{a}}$ & $61,78^{\mathrm{a}}$ & $62,18^{\mathrm{a}}$ & 4,61 \\
Stool dry material (g/day) & $21,32^{\mathrm{a}}$ & $21,72^{\mathrm{a}}$ & $21,89^{\mathrm{a}}$ & $22,02^{\mathrm{a}}$ & 1,95 \\
Dry material digestion (\%) & $64,7^{\mathrm{a}}$ & $64,15^{\mathrm{a}}$ & $64,66^{\mathrm{a}}$ & $64,58^{\mathrm{a}}$ & 8.81 \\
Proximate GE rations (kcal/kg) & 2918,58 & 3068,59 & 3060,07 & 3060,19 & \\
Gross energy consumption (kcal/day) & $175,61^{\mathrm{a}}$ & $196,85^{\mathrm{a}}$ & $197,86^{\mathrm{a}}$ & $197,62^{\mathrm{a}}$ & 9,84 \\
Stool energy (kcal/day) & $62,65^{\mathrm{a}}$ & $66.49^{\mathrm{a}}$ & $66,03^{\mathrm{a}}$ & $66,13^{\mathrm{a}}$ & 4,96 \\
Digestible energy (\%) & $65,37^{\mathrm{a}}$ & $65,02^{\mathrm{a}}$ & $66,62^{\mathrm{a}}$ & $66,54^{\mathrm{a}}$ & 13,48 \\
Proximate protein ration results & $16,78^{\mathrm{a}}$ & 16,29 & 16,08 & 16,19 & \\
Protein consumption (g/day) & $10,11^{\mathrm{a}}$ & $9,87^{\mathrm{a}}$ & $9,93^{\mathrm{a}}$ & $10,07^{\mathrm{a}}$ & 1,17 \\
Fecal protein (g/day) & $4,43^{\mathrm{a}}$ & $4,15^{\mathrm{a}}$ & $4,28^{\mathrm{a}}$ & $4,39^{\mathrm{a}}$ & 1,16 \\
Protein Digestion (\%) & $56,18^{\mathrm{a}}$ & $57,95^{\mathrm{a}}$ & $556,89^{\mathrm{a}}$ & $56,41^{\mathrm{a}}$ & 4,97 \\
\hline
\end{tabular}

R0 : Duck ration without using EM4 fermented grape wine waste

R1 : Duck ration using 5\% EM4 fermented wine waste

R2 : Duck ration using 10\% EM4 wine fermented wine waste

R3 : Duck ration using 15\% EM4 wine fermented wine waste

SEM : Standard error of the treatment

* Values with the same letter indicate no significant difference $(\mathrm{P}>0.05)$

\subsection{Performance}

The results of the study showed duck weight at the beginning of the study was not significantly different ( $P>0.05)$ among the treatments. The reflects on the ducks used in the study have homogeneous body weight. The final body weight of ducks given R0 treatment was $1496.08 \mathrm{~g}$, while the final weight of ducks treated R1, R2, and R3 were $0.20 \%, 0.77 \%$, and $1.84 \%$ higher, but statistically not significantly different (P>0.05). Weight gain during 10 weeks of maintenance, ducks received R0 treatment was $14.11 \mathrm{~g} /$ day while ducks gained weight treatment R1, R2, and R3 rations respectively $0.67 \%, 1.27$, and $2.50 \%$ higher $(\mathrm{P}>0.05)$ unlike in the following Table 3.

The use of wine waste fermented to $15 \%$ level in the male Bali duck ration has not had a significant influence on the growth of male Bali duck cattle. Rations using fermented grape wine waste up to $15 \%$ do not cause a strikingly high crude fiber content in terms of under $5 \%$. They do not exceed the upper threshold of crude fiber content in poultry. The rations R0, R1, R2, and R3 have arranged ISO energy and ISO protein with reference to the standard nutrient requirements of ducks, in accordance with the NCR standard (2001). Rations on the same energy and protein content do not cause a difference in ration consumption (Tami, 2017). Consumption of the same ration causes the consumption of nutrients as well (Tillman et al., 1998). Nutrients consumed by livestock will be used to form the constituent components of the body (bones, meat, and fat) (Nuriyasa et al., 2018). 
The same nutrients consumption on ducks were treated with rations R0, R1, R2, and R3 caused the growth of ducks did not show significant differences. Moote et al., (2012), found the use of grape wine waste about 7\% in the ration of male cattle did not show any significant difference in terms of body weight gain and meat color score compared to controls.

There were no significant differences $(\mathrm{P}>0.05)$ on the consumption of male Bali rations were treated differently with rations (Table 3). Consumption of duck rations received ration treatment for 10 weeks R0, R1, R2, and R3 respectively $63.34 \mathrm{~g}, 63.77 \mathrm{~g}, 65.03 \mathrm{~g}$, and $65.45 \mathrm{~g}$. The consumption of rations was not significantly different was due to the composition of ISO energy and ISO protein compiled (Tami, 2017). Tillman (1998), cattle consume rations aimed at meeting the energy needs in their bodies. Cattle will stop consuming rations when the energy needs in their bodies are met.

Table 3

Effect of the use of wine waste in fermented wine rations on the performance of male Bali ducks

\begin{tabular}{llllll}
\hline \multirow{2}{*}{ Variable } & \multicolumn{4}{c}{ Treatment } & \multirow{2}{*}{ SEM $^{*}$} \\
\cline { 2 - 5 } & R0 & R1 & R2 & R3 & \\
\hline Initial body weight (g) & $508,5^{\mathrm{a}}$ & $504,75^{\mathrm{a}}$ & $507,17^{\mathrm{a}}$ & $511,04^{\mathrm{a}}$ & 10,12 \\
Final body weight (g) & $1496,08^{\mathrm{a}}$ & $1499,18^{\mathrm{a}}$ & $1507,56^{\mathrm{a}}$ & $1523,58^{\mathrm{a}}$ & 17,32 \\
Weight gain (g/day) & $14,11^{\mathrm{a}}$ & $14,21^{\mathrm{a}}$ & $14,29^{\mathrm{a}}$ & $14,47^{\mathrm{a}}$ & 2,35 \\
Consumption of rations (g/day) & $63,34^{\mathrm{a}}$ & $63,77^{\mathrm{a}}$ & $65,03^{\mathrm{a}}$ & $65,45^{\mathrm{a}}$ & 3,27 \\
Feed conversion & $4,49^{\mathrm{a}}$ & $4,49^{\mathrm{a}}$ & $4,55^{\mathrm{a}}$ & $4,53^{\mathrm{a}}$ & 0,16 \\
\hline
\end{tabular}

R0 : Duck ration without using EM4 fermented grape wine waste

R1 : Duck ration using 5\% EM4 fermented wine waste

R2 : Duck ration using 10\% EM4 wine fermented wine waste

R3 : Duck ration using 15\% EM4 wine fermented wine waste

SEM : Standard error of the treatment

*Values with the same letter indicate no significant difference $(\mathrm{P}>0.05)$

The highest conversion of ration occurred in ducks were treated with R3 ration $(4,53)$. It defines the level of efficiency of feed use in ducks fed R3 was the lowest. Conversion of duck rations fed R2, R1, and R0 rations were respectively $0.32 \%, 0.96 \%$, and $2.56 \%$ lower $(\mathrm{P}>0.05)$. Weight gain was slightly higher in ducks given R3 ration. Due to the consumption of rations in ducks received R3 treatment was slightly higher than other treatments. The results of this study are consistent with the results of the study. Puger et al., (2019), who found a higher weight gain related to higher consumption of ration would result in the conversion of the same ration. The condition also indicates grape seeds and skins are rich in phenolic monomer components, for example, catechins, epicatechins, epicatechin-3-0-gallates, and proanthocyanidins (in dimetric, trimetric, and tetrametric) forms that have mutagenic and antiviral effects (Kim et al., 2006). The content of grape seeds contains $74-78 \%$ oligomeric proanthocyanidin and less than $6 \%$ dry weight grape seed extract contains flavonoids that function as natural antioxidants, not affecting the efficiency of ration use yet. The biofermentation process on the aim of increasing its protein and energy content, and decreasing its crude fiber content has not affected the efficiency of ration use yet (Mahardika-Atmaja, 2015).

\section{Conclusion}

It can be concluded referring to the results of the study that the use of wine waste up to $15 \%$ level in the ration. It did not affect the digestibility and performance of Bali ducks.

\section{Acknowledgments}

The authors would like to thank the LP3M of Udayana University for helping the research budget. Also thanks to the Rector of Udayana University, the Dean of the Faculty of Animal Science at Udayana University for their help in provided various facilities for research. Therefore, it could be accordingly conducted.

Puger, A. W., \& Nuriyasa, I. M. (2019). Ration digest value and performance of male Bali ducks feed waste wine fermented with different levels. International Journal of Life Sciences, 3(3), 1-7. https://doi.org/10.29332/ijls.v3n3.341 


\section{References}

Bagiarta, N., Doswell, R., \& Peter, L. (1989). A View of Existing Manpower and Corresponding Training Needs: Tourist Accommodation and Restaurants in Indonesia. Geneva: ILO/UNDP.

Baumgärtel, T., Kluth, H., Epperlein, K., \& Rodehutscord, M. (2007). A note on digestibility and energy value for sheep of different grape pomace. Small Ruminant Research,67(2-3), 302-306. https://doi.org/10.1016/j.smallrumres.2005.11.002

BPS Buleleng. (2018). Produksi Buah Anggur di Kabupeten buleleng. Badan Pusat Statistik Kabupeten Buleleng. (serial online) [cited 2015 Jul 8]. Available from: http://www.buleleng.bps.go.id

González-Centeno, M. R., Knoerzer, K., Sabarez, H., Simal, S., Rosselló, C., \& Femenia, A. (2014). Effect of acoustic frequency and power density on the aqueous ultrasonic-assisted extraction of grape pomace (Vitis vinifera L.)-a response surface approach. Ultrasonics sonochemistry, 21(6), 2176-2184. https://doi.org/10.1016/j.ultsonch.2014.01.021

Kim, J. W., Tchernyshyov, I., Semenza, G. L., \& Dang, C. V. (2006). HIF-1-mediated expression of pyruvate dehydrogenase kinase: a metabolic switch required for cellular adaptation to hypoxia. Cell metabolism, 3(3), 177-185. https://doi.org/10.1016/j.cmet.2006.02.002

Mahardhika, G., Ismail, M., \& Nordin, R. (2015). Vertical handover decision algorithm using multicriteria metrics in heterogeneous wireless network. Journal of Computer Networks and Communications, 2015. http://dx.doi.org/10.1155/2015/539750

Mahardika, I. K., Harijanto, A., \& Winata, M. S. (2017). Fluid Dynamic Learning Assisted By Student Worksheet Based Rvm with Setting PBL. The International Journal of Social Sciences and Humanities Invention, 4(8), 3830-3833.

Mahardika, K., \& Mastuti, I. (2015). The effects of crude recombinant viral protein vaccines against grouper sleepy disease iridovirus (GSDIV) on humpback grouper (Cromileptes altivelis). Indonesian Aquaculture Journal, 10(2), 163-172.

Mastika, I. M. (2013). Potensi pertanian dan industri pertanian serta pemanfaatannya untuk makanan ternak. Denpasar (USA): Penerbit Universitas Udayana.

Molina-Alcaide, E., Moumen, A., \& Martín-García, A. I. (2008). By-products from viticulture and the wine industry: potential as sources of nutrients for ruminants. Journal of the Science of Food and Agriculture, 88(4), 597-604. https://doi.org/10.1002/jsfa.3123

Moote, P., Church, J., \& Schwartzkopf-Genswein, K. Van Hamme. 2012. Effect of fermented winery waste supplemented rations on beef cattle temperament, feed intake, growth performance and meat quality. Submitted Article, Kamloops, BC, Canada: Thompson Rivers University.

National Research Council. (2012). Nutrient requirements of swine. National Academies Press.

Nuriyasa, I. M., Puspani, E., \& Yupardhi, W. S. (2018). Performance and carcass of local rabbit (Lepus nigricollis) fed concentrate on different levels based on carrot leaf waste (Daucus carota L.). International journal of life sciences, 2(3), 13-19. https://doi.org/10.29332/ijls.v2n3.189

Nuriyasa, M., Antoninho, S. C., \& Rusdianta, I. G. (2017). Effect of Various Level of Fermented Coffee Pulp on Performance of Duroc Pig Cross Bred (sus vitatus) on the Age of 8-12 Weeks. International Journal of Multidisciplinary Approach \& Studies, 4(6).

Partama, I. B., Yadnya, T. G., Trisnadewi, A. A. A. S., \& Sukada, I. K. (2018). Fermented rice husk utilization of effective microorganisms-4 supplemented with Piper betle L. performance, meat quality, antioxidant capacity, and meat cholesterol levels of Bali duck. International Journal of Life Sciences, 2(3), 98-110. https://doi.org/10.29332/ijls.v2n3.215

Prasad, R., Karim, S. A., \& Patnayak, B. C. (2010). Growth performance of broiler rabbits maintained on diets with varying levels of energy and protein. World Rabbit Science, 4(2), 75-78. https://doi.org/10.4995/wrs.1996.274

Puger, A. W., Puspani, E., Nuriyasa, I. M., \& Yupardhi, W. S. (2019). Effects of replacement of fish mill with golden snail mill in ration to performance of male Bali duck. International journal of life sciences, 3(1), 2530. https://doi.org/10.29332/ijls.v3n1.243

Puger, A., Puspani, E., Nuriyasa, I., \& Yupardhi, W. S. (2019). Effects of replacement of fish mill with golden snail mill in ration to performance of male Bali duck. International Journal of Life Sciences, 3(1), 25-30. https://doi.org/10.29332/ijls.v3n1.243 
Rakhmani, S. I. W. (2005). Peningkatan nilai gizi bahan pakan dari limbah pertanian melalui fermentasi. Prosiding Lokakarya Nasional Potensi dan Peluang Pengembangan Usaha Agrobisnis Kelinci. Balai Penelitian Ternak, Bogor.

Tami, I. W. (2017). Pengaruh Penggantian Tepung Ikan dengan Tepng Keong Mas pada Level Berbeda dalam Pakan Terhadap Penampilan Entok (Doctoral dissertation, Tesis. Program Studi Megister Ilmu Peternakan. Fakultas Peternakan. Universitas Udayana. Bali).

Tillman, A. M., Svingby, M., \& Lundström, H. (1998). Life cycle assessment of municipal waste water systems. The international journal of life cycle assessment,3(3), 145-157. https://doi.org/10.1007/BF02978823

Tillman, N., Ulman, A., \& Elman, J. F. (1989). Oxidation of a sulfide group in a self-assembled monolayer. Langmuir, 5(4), 1020-1026. https://doi.org/10.1021/la00088a024

Voisinet, B. D., Grandin, T., O'Connor, S. F., Tatum, J. D., \& Deesing, M. J. (1997). Bos indicus-cross feedlot cattle with excitable temperaments have tougher meat and a higher incidence of borderline dark cutters. Meat science, 46(4), 367-377. https://doi.org/10.1016/S0309-1740(97)00031-4

Yadnya, T. B., Trisnadewi, A. A., Sukada, I. K., \& Oka, I. G. L. (2016). The effect of fermented purple sweet potato (ipomoea batatas l) skin in diets on feed and anthocyanin consumption, carcass characteristics, anthioxidant profile and meat texture of Bali duck. International Research Journal of Engineering, IT \& Scientific Research, 2(9), 73-80.

Yadnya, T. G. B., Trisnadewi, A. A. A. S., Sukada, I. K., \& Oka, I. G. L. (2016). The effect of offered diet containing rice hull and mono sodium glutamate (msg) and effective microorganism -4 (em-4) solution on the performance of campbell duck. International Research Journal of Engineering, IT \& Scientific Research, 2(11), 75-82.

\section{Biography of Authors}

\begin{tabular}{|l|l||}
\hline & $\begin{array}{l}\text { Ir. Anthonius Wayan Puger, MS. was born in Tangeb, Bali, Indonesia, 25 January } \\
\text { 1958. He is an associate professor, Faculty of Animal Science, Udayana University, } \\
\text { at Jimbaran District, Badung Regency, Indonesia, Ph. +62361701772, P.B } \\
\text { Sudirman Street, Bali, Indonesia, Ph. +6261222096, +62361222096. He lives at Jn. } \\
\text { Dukuh Sari, Kelurahan Abian Base, Mengwi, Denpasar Regency, Bali, Indonesia, Ph. } \\
+628123995907 \\
\text { Email: anton.puger@gmail.com }\end{array}$ \\
\hline \hline & $\begin{array}{l}\text { Dr. Ir. I Made Nuriyasa, MS., was born in Tabanan, Bali, Indonesia, 20 February } \\
\text { 1962. He is an associate professor, Faculty of Animal Science, Udayana University } \\
\text { at Jimbaran District, Badung Regency, Indonesia, Ph. +62361701772), P.B } \\
\text { Sudirman Street, Bali, Indonesia Ph. +62361222096, Fax. +62361222096. He lives } \\
\text { at Jalan Sriwijaya, No. 25 Tabanan Regency, Bali, Indonesia, Fax. +6282237230123 } \\
\text { Email: madenuriyasa@ @unud.ac.id }\end{array}$ \\
\hline
\end{tabular}

Puger, A. W., \& Nuriyasa, I. M. (2019). Ration digest value and performance of male Bali ducks feed waste wine fermented with different levels. International Journal of Life Sciences, 3(3), 1-7. https://doi.org/10.29332/ijls.v3n3.341 